\title{
Calcium Localization and Tipburn Development in Lettuce Leaves during Early Enlargement
}

\author{
Daniel J. Barta ${ }^{1}$ and Theodore W. Tibbitts \\ Department of Horticulture, University of Wisconsin, Madison, WI 53706
}

\begin{abstract}
AdDitional Index words. Lactuca sativa, physiological disorder, deficiency, magnesium, potassium, electron microprobe, $\mathrm{X}$-ray analysis

Abstract. Tissue concentrations of $\mathrm{Ca}, \mathrm{Mg}$, and $\mathrm{K}$ were determined across immature leaves of lettuce (Lactuca sativa $\mathrm{L}$. 'Buttercrunch') at different stages of enlargement using electron microprobe $x$-ray analysis. The analysis was with a wavelength dispersive spectrometer to permit detection of low concentrations of Ca. Patterns of mineral accumulation in immature leaves that were exposed were compared to patterns of accumulation in leaves that were enclosed within a developing head. The leaves developing without enclosure were free to transpire and developed normally whereas leaves developing with enclosure were restricted in transpiration and developed an injury that was characteristic of Ca

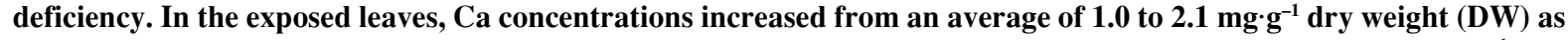
the leaves enlarged from 5 to $30 \mathrm{~mm}$ in length. In the enclosed leaves, Ca concentrations decreased from 1.0 to $0.7 \mathrm{mg} \cdot \mathrm{g}^{-1} \mathrm{DW}$ as the leaves enlarged from 5 to $30 \mathrm{~mm}$ in length. At the tips of these enclosed leaves a larger decrease was found, from 0.9 to $0.3 \mathrm{mg} \cdot \mathrm{g}^{-1} \mathrm{DW}$ during enlargement. Necrotic injury first became apparent in this tip area when the concentration was $\approx 0.4 \mathrm{mg} \cdot \mathrm{g}^{-1} \mathrm{DW}$. Magnesium concentrations across the exposed leaves were similar to concentrations across the enclosed leaves, and did not change with enlargement. Magnesium concentrations averaged 3.5. $\mathrm{mg}^{-1} \mathrm{DW}$ in both enclosed and exposed leaves during enlargement from 5 to $30 \mathrm{~mm}$. In both exposed and enclosed leaves, $K$ concentrations increased during enlargement from 40 to $\approx 60 \mathrm{mg} \cdot \mathrm{g}^{-1} \mathrm{DW}$. Potassium concentrations were highest toward the leaf apex and upper margin where injury symptoms occurred, and this may have enhanced injury development. This research documents the critical low levels of $\mathrm{Ca}\left(0.2\right.$ to $\left.0.4 \mathrm{mg} \cdot \mathrm{g}^{-1} \mathrm{DW}\right)$ that can occur in enclosed leaves of plants and which apparently leads to the marginal apex necrosis of developing leaves seen frequently on lettuce and other crops.
\end{abstract}

Enclosure of leaves at the growing point of plants leads to reduced $\mathrm{Ca}$ concentrations and frequently a tipburn injury of these leaves. (Barta and Tibbitts, 1986; Bradfield and Guttridge, 1979; Palzkill et al., 1980; Tibbitts et al., 1983; Van Berkel, 1988). The enclosure reduces transpiration and thus reduces $\mathrm{Ca}$ transport (Collier and Tibbitts, 1982; Marschner, 1995), as most $\mathrm{Ca}$ transport in plants occurs mainly in the xylem by mass flow (Clarkson, 1984). This mass flow results from several factors including transpiration, root pressure, and diurnal changes in water stress (Marschner, 1983). Although Ca is generally considered phloem immobile, the phloem does contain low concentrations of $\mathrm{Ca}$ (Bangerth, 1979; Clarkson, 1984) and thus provides some $\mathrm{Ca}$ to tissues.

Enlarging leaves have a high requirement of $\mathrm{Ca}$ for formation and expansion of cell walls (Clarkson, 1984; Demarty et al., 1984; Marschner, 1995). When young leaves become photosynthetically competent, the rate of nitrate reduction is initially high, leading to the formation of organic acids which have a high affinity for Ca (Kirkby and Knight; 1977 , Van Egmond and Breteler, 1972). Thus developing tissues require a continuous, adequate supply of $\mathrm{Ca}$ during enlargement.

It was the purpose of this study to determine Ca concentrations in areas of developing lettuce leaves during the early stages of leaf enlargement, and compare these to concentrations of $\mathrm{K}$ and $\mathrm{Mg}$ in these same areas of the leaves. Patterns of nutrient accumula-

Received for publication 26 Apr. 1999. Accepted for publication 31 Jan. 2000. This work was supported by the College of Agricultural and Life Sciences, Univ. of Wisconsin-Madison, the Graduate School, Univ. of Wisconsin-Madison, and NASA Grant NCC2-136. The advice and facilities for analytical procedures, provided by Everett Glover, Dept. of Geology and Geophysics, Univ. of Wisconsin-Madison, is gratefully acknowledged. The cost of publishing this paper was defrayed in part by the payment of page charges. Under postal regulations, this paper therefore must be hereby marked advertisement solely to indicate this fact. ${ }^{1}$ Current address: NASA Johnson Space Center, Mailcode EC3, Houston TX 77058 . tion in exposed leaves that can transpire freely were compared to patterns in enclosed leaves that were restricted in transpiration and subject to $\mathrm{Ca}$ deficiency injuries. An analysis procedure was used that permitted an accurate determination of the anticipated low concentrations of $\mathrm{Ca}$ in small discrete areas of these leaves.

\section{Materials and Methods}

Plants of Lactuca sativa 'Buttercrunch', a butterhead lettuce, were grown in a walk-in growth chamber (model CEL 512-37; Sherer-Gillett, Marshall, Mich.). Six seeds were sown in each of $601-\mathrm{L}$ white plastic pots, containing a medium of 1 peat : 1 vermiculite $(\mathrm{v} / \mathrm{v})$. The pots were watered four times daily to excess with a modified, half-strength Hoagland nutrient solution (Hammer et al., 1978) at a pH of 6.4. Positions of the pots within the growth room were randomly changed several times during the course of the experiment. A 16-h photoperiod was provided by cool-white fluorescent lamps at a photosynthetic photon flux of $350 \pm 35 \mu \mathrm{mol} \cdot \mathrm{m}^{-2} \cdot \mathrm{s}^{-1}$, averaged across the pots over the length of the experiment. Air temperature and relative humidity averaged $20 \pm 1{ }^{\circ} \mathrm{C}$ and $65 \% \pm 5 \%$, respectively, during both the light and dark periods.

After $12 \mathrm{~d}$, the pots were thinned to the modal two plants based on the size of the first true leaf. The pots were thinned to one plant per pot by harvests when leaf 5 , the outer exposed leaf, reached a length of $5 \mathrm{~mm}$ to $30 \mathrm{~mm}$ (Fig. 1). Twelve plants were harvested at about daily intervals to obtain plants with leaf 5 at lengths of (average \pm range) of $5 \pm 0.5,10 \pm 0.5,20 \pm 1.0$, and $30 \pm 0.5 \mathrm{~mm}$. The remaining plant in each pot was grown for an additional period of $\approx 5 \mathrm{~d}$ and plants harvested again at about daily intervals when leaf 14 , an enclosed leaf, reached lengths (average \pm range) of $5 \pm 1.1,10 \pm 1.0,20 \pm 2.0$, and $30 \pm 2.5 \mathrm{~mm}$. At each harvest, the individual leaves on each plant were observed for the presence of injury symptoms. Only one leaf from each of two plants from each harvest was selected that had a length closest to the target 


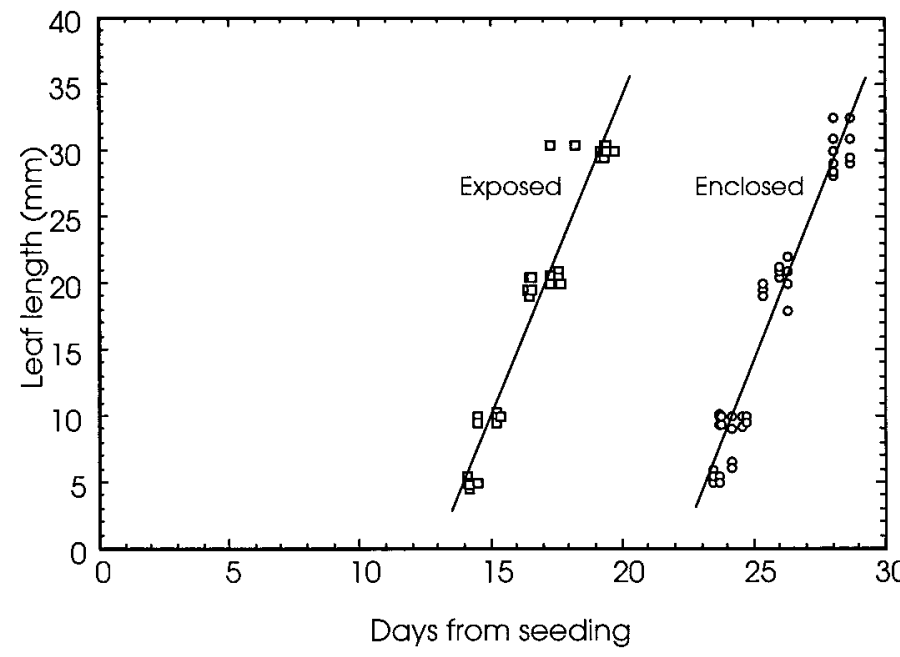

Fig. 1. Elongation of exposed and enclosed lettuce leaves of developing lettuce plants. Each symbol represents a leaf from separate plants harvested on the indicated days from seeding.

harvest size. These selected leaves were excised for electron microprobe $\mathrm{x}$-ray analysis.

In previous studies it was found that the 14th leaf, counted from the cotyledons, developed $\mathrm{Ca}$ deficiency symptoms with high frequency under these environmental conditions. This leaf enlarged within the enclosure of several surrounding leaves that minimized its potential for transpiring. The 5th leaf was exposed and always devoid of symptoms. This leaf was exposed to light and the ambient chamber atmosphere early in its development and thus could transpire freely.

Immediately after excision, the selected leaves were cut into 5mm-wide strips, quick-frozen in liquid nitrogen, and stored at $80^{\circ} \mathrm{C}$ before drying. Samples were dried under vacuum at $-20^{\circ} \mathrm{C}$ and stored in a desiccator until mounting. The dried pieces of each selected leaf were attached to $25.4 \mathrm{~mm}$ diameter aluminum mounts using double-stick tape. An edge of each sample was secured to the mount by quick drying epoxy resin. Samples were coated with evaporated carbon to enhance electron conduction, which prevented charging.

An electron microprobe (model SEM-Q; Applied Research Laboratories, Inc., Sun Valley, Calif.) equipped with wavelength-dispersive spectrometers for X-ray separation was used for analysis of the plant tissue. Analysis was made for $\mathrm{Ca}, \mathrm{Mg}$, and $\mathrm{K}$ following procedures detailed in Barta and Tibbitts (1991b).

To establish concentration gradients across the leaves, analyses were performed along four transects on one-half of each leaf. Each transect extended from the midrib to the margin, roughly perpendicular to the secondary veins. The first measurement transect extended along the upper margin. The remaining three were spaced evenly across the rest of the leaf. Along each transect, three to five locations were analyzed for $\mathrm{Ca}, \mathrm{Mg}$, and $\mathrm{K}$. At each location an average concentration was calculated from analysis of two points not more than $500 \mu \mathrm{m}$ apart. Only interveinal locations were selected to avoid confounding effects caused by both incomplete beam penetration on veinal areas and by higher concentrations present in vascular tissue.

The depth of beam penetration was determined to be between 50 and $55 \mu \mathrm{m}$ and the beam irradiated $\approx 1 \times 10^{-4} \mathrm{~mm}^{3}$ of tissue. Thus, each analysis involved measurement of the average concentration of element in 10 to 30 cells. The beam did not penetrate the leaf completely and only $40 \%$ to $70 \%$ of the leaf cross-section was analyzed. However, initial studies had shown that concentrations within interveinal areas of these immature leaves were similar throughout the leaf cross-section (Barta and Tibbitts, 1991b). These similar concentrations within the leaf were also found in beech (Fagus sylvatica L.) leaves with electron microprobe analysis (Thiec et al., 1995). Analyses were performed through the lower epidermis, with the leaf surface parallel to the mount and perpendicular to the electron beam. This orientation was found to be most useful for estimates of the average concentration of $\mathrm{Ca}, \mathrm{Mg}$, and $\mathrm{K}$ across the leaf profile.

The measured concentrations of each element are presented on illustrations of idealized leaves drawn from leaf clearings showing locations of major veins. The results from the two replicate leaves were combined and are reported as average concentrations at each location across the leaf.

\section{Results}

Tipburn injury began to develop in plants at $22 \mathrm{~d}$ after seeding. Marginal injury first occurred on each plant on the ninth, tenth or eleventh leaf and continued on all successive leaves that developed. Injury symptoms were first apparent on leaves when they were 20 to $30 \mathrm{~mm}$ in length. When the enclosed 14th leaves were $20 \mathrm{~mm}$ long, 33\% had tipburn, and when $30 \mathrm{~mm}$ long, $83 \%$ showed injury. Injury was restricted to the leaf apex and distal margin and was characterized by watersoaking, laminal and veinal necrosis, and laticifer rupture. None of the exposed leaves exhibited any injury symptoms.

Calcium concentrations across the sampled exposed and enclosed leaves are presented in Fig. 2. When $5 \mathrm{~mm}$ long, Ca concentrations were relatively uniform across both leaves, and averaged $1.0 \mathrm{mg} \cdot \mathrm{g}^{-1} \mathrm{DW}$. At $10 \mathrm{~mm}$ in length, a slight reduction in Ca concentrations was observed in the distal portion of both leaves, and this decrease was more pronounced in the enclosed leaves. By $20 \mathrm{~mm}$ long, Ca concentrations in the exposed leaf had increased dramatically, particularly toward the apex, reversing the earlier pattern of greater accumulation toward the base. Calcium concentrations were highest along the midrib and upper margin. The highest concentration of $\mathrm{Ca}$ in the $20 \mathrm{~mm}$ leaf, 3.1 $\mathrm{mg} \cdot \mathrm{g}^{-1} \mathrm{DW}$, was found at the terminus of the midvein, at the leaf apex. At $30 \mathrm{~mm}$ in length, a further increase in Ca across the exposed leaf was noted. Calcium was highest at the upper margin and along the midrib, and generally decreased both laterally and basipetally. In contrast, Ca concentrations across the enclosed leaves continued to decrease during enlargement, particularly in the distal marginal areas. At $30 \mathrm{~mm}$ in length, Ca concentrations as low as $0.2 \mathrm{mg} \cdot \mathrm{g}^{-1} \mathrm{DW}$ were found along the margin associated with areas of injury development as noted by the shading in these figures. Calcium concentrations in basal areas remained relatively unchanged during this development period. Average $\mathrm{Ca}$ concentrations for the leaves were $1.0,0.9,1.6$, and $2.1 \mathrm{mg} \cdot \mathrm{g}^{-1}$ DW for the exposed leaves and $0.9,0.7,0.7$, and $0.7 \mathrm{mg} \cdot \mathrm{g}^{-1} \mathrm{DW}$ across the enclosed leaves, when 5, 10, 20, and $30 \mathrm{~mm}$ long, respectively. Thus, exposed leaves exhibited a large increase in $\mathrm{Ca}$ over this period of leaf enlargement whereas enclosed leaves exhibited no increase.

Magnesium concentrations across the sampled exposed and enclosed leaves when 5, 10, 20, and $30 \mathrm{~mm}$ long are presented in Fig. 3. Magnesium concentrations were relatively uniform across both leaves throughout enlargement, most values were between 2.5 and $4.5 \mathrm{mg} \cdot \mathrm{g}^{-1} \mathrm{DW}$. There were no apparent differences in 

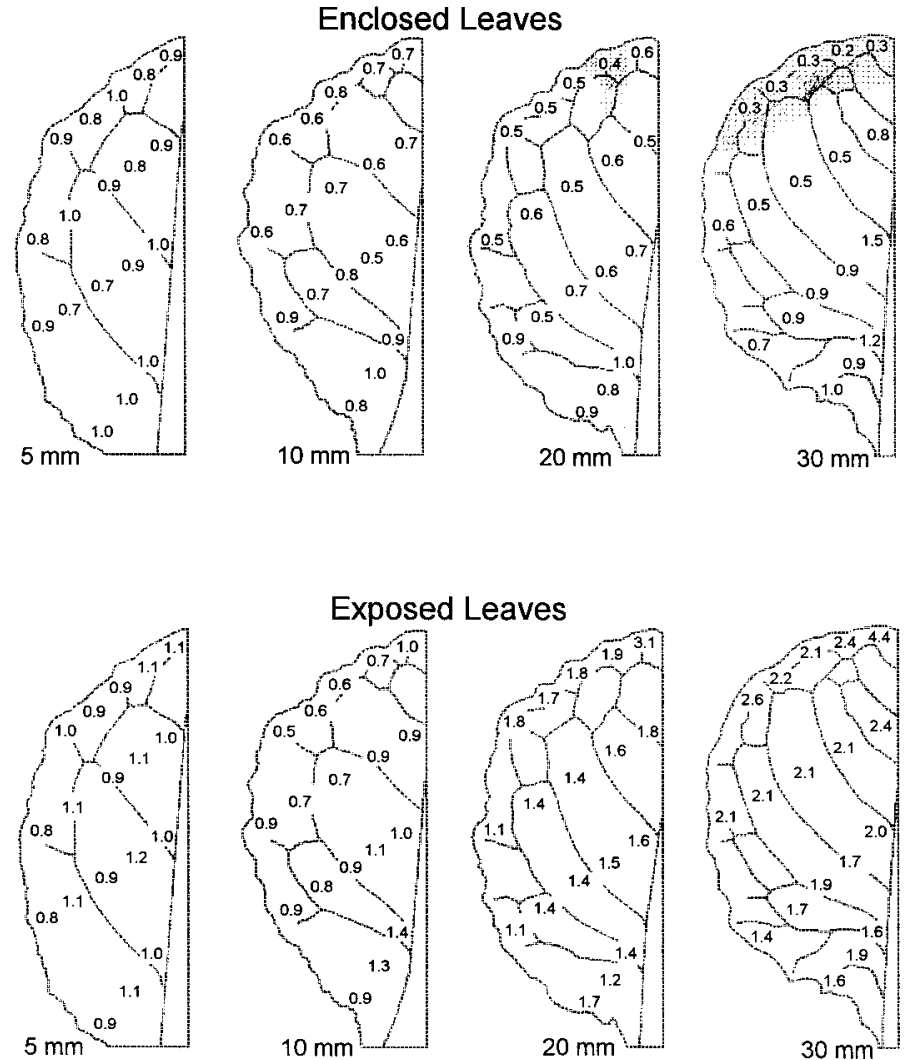

Fig. 2. Calcium concentrations, $\mathrm{mg} \cdot \mathrm{g}^{-1}$ dry weight, in enclosed and exposed lettuce leaves during enlargement. Concentrations are averages of two replicate leaves. The leaf length is indicated at the bottom of each leaf. Areas showing collapse and tipburn injury are shaded.

concentration between the exposed and enclosed leaves, with the exception that some severely injured areas on the 30-mm-long enclosed leaves had higher $\mathrm{Mg}$ concentrations. Average $\mathrm{Mg}$ concentrations for the leaves were $3.8,3.6,3.2$, and $3.5 \mathrm{mg} \cdot \mathrm{g}^{-1}$ DW for the exposed leaf and $3.4,3.6,3.3$, and $3.4 \mathrm{mg} \cdot \mathrm{g}^{-1} \mathrm{DW}$ for the enclosed leaf, when 5, 10, 20, and $30 \mathrm{~mm}$ long, respectively.

Potassium concentrations across the sampled exposed and enclosed leaves when 5,10,20, and $30 \mathrm{~mm}$ long are presented in Fig. 4. In contrast to $\mathrm{Mg}$, large gradients in $\mathrm{K}$ concentration developed across both leaves during enlargement. Potassium concentrations tended to be greater in an acropetal direction but less laterally from the midrib. The gradients were small when leaves were $5 \mathrm{~mm}$ long, and became greater during enlargement. At $30 \mathrm{~mm}$ in length, $\mathrm{K}$ levels in the apical regions were almost 2fold higher than in the base. The highest $\mathrm{K}$ concentrations were found at the terminus of the midvein at the leaf apex. The gradient of decreasing $\mathrm{K}$ from midrib to margin was less consistent in the enclosed leaves than the exposed leaves.

Average K concentrations for the leaves were 46, 50, 56, 64 $\mathrm{mg} \cdot \mathrm{g}^{-1} \mathrm{DW}$ for the exposed leaves and $38,42,46$, and $50 \mathrm{mg} \cdot \mathrm{g}^{-1} \mathrm{DW}$ for the enclosed leaves, when $5,10,20$, and $30 \mathrm{~mm}$ long, respectively.

\section{Discussion}

The tissue concentration of $\mathrm{Ca}$ found in this study to encourage injury to lettuce was $\leq 0.4 \mathrm{mg} \cdot \mathrm{g}^{-1} \mathrm{DW}$ and is considerably less than the critical levels reported previously for calcium-related injuries in leaf tissues by most researchers (Cresswell, 1991; Huett, 1994; Thibodeau and Minotti, 1969). However these previous analyses of leaf tissue were confounded by 1) increases in Ca concentrations occurring after initiation of injury and before sampling for analyses, 2) unavailability of procedures to analyze small discrete areas of tissue, and 3) inclusion of veinal tissue which had higher concentrations of $\mathrm{Ca}$ (Barta and Tibbitts, 1991a). This Ca concentration of $0.4 \mathrm{mg} \cdot \mathrm{g}^{-1}$ is considerably below the concentration ( 1 to $2 \mathrm{mg} \cdot \mathrm{g}^{-1} \mathrm{DW}$ ) that Loneragan and Snowball (1969) proposed as a functional minimum for normal growth of dicotyledonous plants. Nonetheless these low concentrations of $\mathrm{Ca}$ are similar to the concentrations reported for Ca-related physiological disorders of fruit and certain storage organs (Al-Ani, 1978; Cerda et al., 1979; Fallahi et al., 1988). Fruit and storage tissues, as potatoes (Solanum tuberosum L.), provide large amounts of uniform tissue for effective analysis of low concentrations of $\mathrm{Ca}$ by atomic absorption spectrometry.

The declining gradient in Ca concentration from base to apex in Ca deficient leaves described in this paper is consistent with observations of patterns of ${ }^{45} \mathrm{Ca}$-deficient leaves reported by others (Chiu and Bould, 1976; Millikan and Hanger, 1964; Pressman et al., 1993)), with Ca accumulation generally confined to vascular tissues in the basal portion of the leaf. Tissues at the apex and distal margin are first to mature, because cell elongation and maturation occur basipetally during leaf ontogeny, once veination has been established (Olson et al., 1969). The supply of $\mathrm{Ca}$ is apparently not sufficient to sustain normal development at the apex and distal areas once the leaf initiates rapid elongation and maturation. Injury development also follows this basipetal progression of deficiency.

Reasons for the decrease in Ca concentration in marginal areas
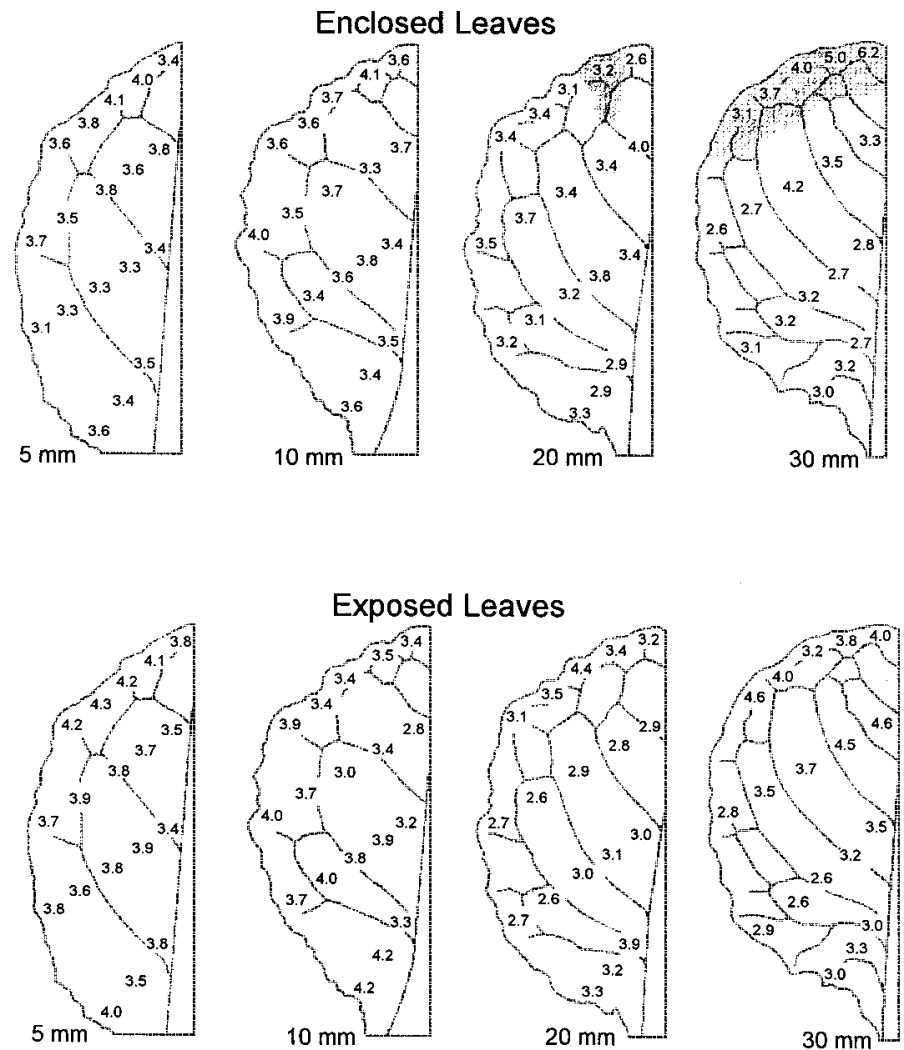

Fig. 3. Magnesium concentrations, $\mathrm{mg} \cdot \mathrm{g}^{-1}$ dry weight, in enclosed and exposed lettuce leaves during enlargement. Concentrations are averages of two replicate leaves. The leaf length is indicated at the bottom of each leaf. Areas showing collapse and tipburn injury are shaded. 

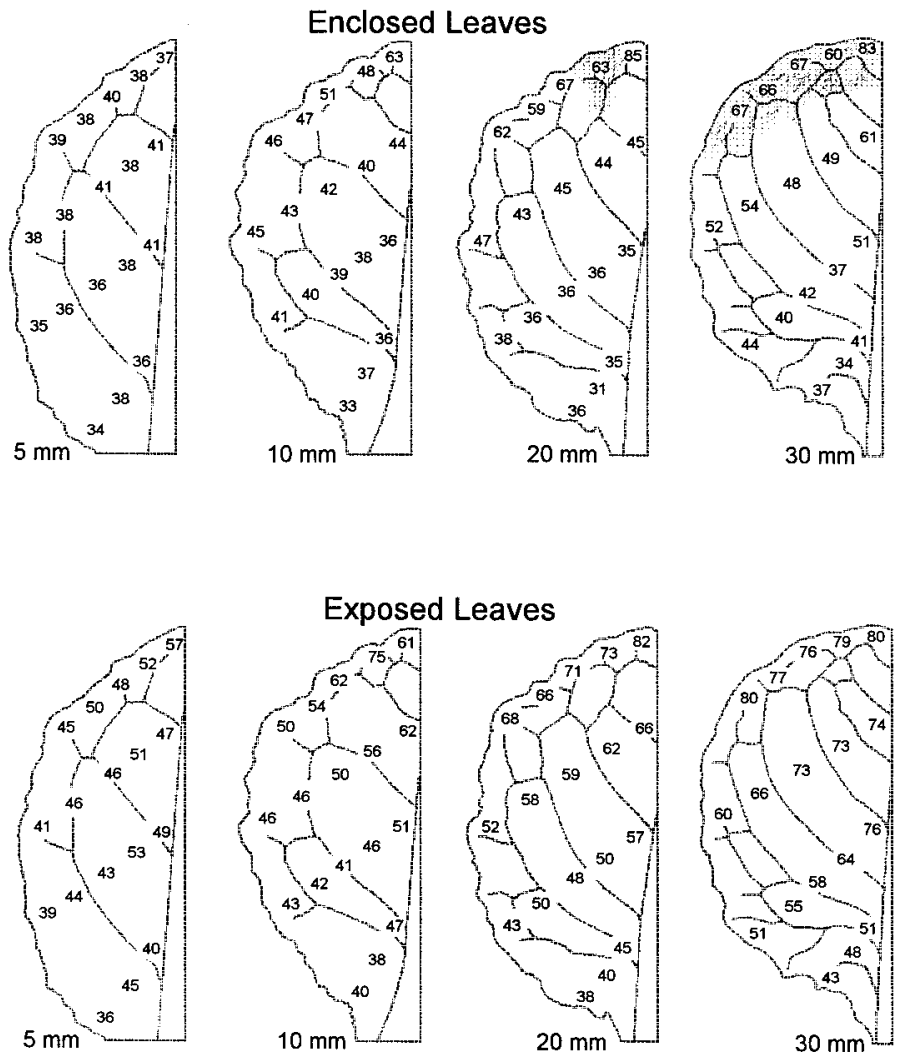

Fig. 4. Potassium concentrations, $\mathrm{mg} \cdot \mathrm{g}^{-1}$ dry weight, in enclosed and exposed lettuce leaves during enlargement. Concentrations are averages of two replicate leaves. The leaf length is indicated at the bottom of each leaf. Areas showing collapse and tipburn injury are shaded.

of the enclosed leaves during enlargement are likely associated with restricted transport of $\mathrm{Ca}$ into these tissues. These enclosed leaves were encircled by surrounding leaves during the study and thus would not be expected to have any significant transpirational water movement for accumulation of $\mathrm{Ca}$. Alternative modes of Ca transport, as by root pressure during the dark period or by water movement with turgor cycling over successive light and dark periods (Marschner, 1983; Tibbitts and Palzkill, 1979), must not have occurred to any significant degree in the plants of this study.

In the exposed leaves, rapid accumulation of $\mathrm{Ca}$ did not occur until the leaf was between 10 and $20 \mathrm{~mm}$ in length, even though the leaf was not enclosed and transpiration was not restricted from the beginning of its development. It is likely that the vascular and stomatal tissues necessary to support transpiration did not mature until the leaf reached this size (Olson et al., 1969). The highest Ca levels in the exposed leaves were first observed at the leaf apex, concomitant with the apex to basipetal trend in leaf maturation.

This research measured the total quantity of $\mathrm{Ca}$ (soluble + insoluble forms) in lettuce tissues. Thus, the low concentrations of total $\mathrm{Ca}$ found contradict evidence by Misaghi and Grogan (1978) and Thibodeau and Minotti (1969) that tipburn results from chelation or binding of $\mathrm{Ca}$ by organic acids or other cellular metabolites. Chelation or binding would reduce soluble $\mathrm{Ca}$ but not affect the total $\mathrm{Ca}$ concentration.

The concentrations of $\mathrm{Mg}$ and $\mathrm{K}$ found in the leaves are typical for lettuce grown under controlled environment conditions (Berry et al., 1981). The locally high levels of $\mathrm{Mg}$ associated with some injured areas in this study also was found in apples [Malus sylvestris (L.) Mill. var. domestica (Borkh.) Mansf.] (Hopfinger and Poovaiah, 1979) and potato tissues (Barta, personal observations) exhibiting Ca deficiency injuries. This high $\mathrm{Mg}$ concentration may be due to $\mathrm{Mg}$ accumulation resulting from cellular dysfunction during injury development. High levels of $\mathrm{K}$ also were associated with sites exhibiting $\mathrm{Ca}$ deficiency symptoms. The high levels of $\mathrm{K}$ in marginal areas may aggravate the $\mathrm{Ca}$ related disorder by causing a higher requirement for $\mathrm{Ca}$ to maintain membrane integrity (Bangerth, 1979). However it must be recognized that the injured tissue would also have had some collapse and thus X-ray penetration may have involved a greater proportion of the leaf, causing increases in the measured concentrations.

The relative concentrations of $\mathrm{K}: \mathrm{Mg}: \mathrm{Ca}(\mathrm{K}>>\mathrm{Mg}>\mathrm{Ca})$, in leaves 5 to $30 \mathrm{~mm}$ long, is consistent with concentrations that would be expected when mineral transport occurs through the apoplast and exchange reactions control the concentration balance of these elements (Bell and Biddulph, 1963; Demarty et al., 1984). Exchange sites within the cell walls of the xylem and other tissues are assumed to absorb cations in relation to their position in the Hofmeister and lyotropic series. These exchange sites have the highest affinity for $\mathrm{Ca}$, less for $\mathrm{Mg}$ and least for $\mathrm{K}$. Thus $\mathrm{Ca}$, and to a lesser extent $\mathrm{Mg}$, would be removed preferentially from the apoplastic fluid during transport and would be less available for accumulation in developing leaves and other distal organs. However, the rather similar concentrations of $\mathrm{Mg}$ in the enclosed and exposed leaves, indicates that other mechanisms must also be controlling the relative proportions of cations found in the lettuce tissues.

The ratio of $\mathrm{K}: \mathrm{Mg}: \mathrm{Ca}$ concentrations found in the 5- to 10 mm-long leaves $(44: 4: 1)$, is similar to ratios found in phloem sap of several species $(45: 2: 1)$, but not the apoplastic fluid within the xylem (2:0.2:1)(Hocking, 1980, Jeschke and Pate, 1991; Pate and Hocking, 1978). The similarity in ratios of $\mathrm{K}: \mathrm{Mg}: \mathrm{Ca}$ in the young developing tissue and in the phloem suggests that the phloem may be supplying a significant portion of the Ca early in leaf ontogeny. A leaf is heterotrophic early in its development, depending upon phloem transport for carbon, water, and many essential mineral nutrients for growth. Phloem elements differentiate ahead of the tracheary elements in lettuce (Olson et al., 1969), and are the first functional conducting tissue available to cells in a developing leaf. Because the $\mathrm{Ca}$ requirement of the interveinal tissues of the 5 to $10 \mathrm{~mm}$ long leaves is very low, $\approx 1 \mathrm{mg} \cdot \mathrm{g}^{-1} \mathrm{DW}$, the low levels of $\mathrm{Ca}$ in the phloem sap could be adequate to sustain early leaf growth before xylem differentiation is completed.

Further research is needed to understand how physiological and developmental changes in young growing leaves affect the magnitude and mode of Ca transport. It is of particular importance to understand how these changes interact under the environmental conditions that encourage Ca-related injuries.

\section{Literature Cited}

Al-Ani, A.M. 1978. Postharvest physiology of 'Anjou' pear fruit: Relations between mineral nutrition and corkspot, respiration, and ethylene evolution. PhD diss., Ore. State Univ., Corvallis.

Bangerth, F. 1979. Calcium-related physiological disorders of plants. Annu. Rev. Phytopathol. 17:97-122.

Barta, D.J. and T.W. Tibbitts. 1986. Effects of artificial enclosure of young lettuce leaves on tipburn incidence and leaf calcium concentration. J. Amer. Soc. Hort. Sci. 111:413-416.

Barta, D.J. and T.W. Tibbitts. 1991a. Calcium localization in lettuce leaves with and without tipburn: Comparison of controlled environment and field grown plants. J. Amer. Soc. Hort. Sci. 116:870-875. 
Barta, D.J. and T.W. Tibbitts. 1991b. Use of electron microprobe X-ray analysis for determination of low calcium concentrations in leaf tissue. Commun. Soil Sci. Plant Analysis. 22:729-753.

Bell, C.W. and O. Biddulph. 1963. Translocation of calcium. Exchange versus mass flow. Plant Physiol. 38:610-614.

Berry, W.L., D. T. Krizek, D.P. Ormrod, J.C. McFarlane, R.W.Langhans, and T.W. Tibbitts. 1981. Variation in elemental content of lettuce grown under base-line conditions in five controlled-environment facilities. J. Amer. Soc. Hort. Sci. 106:661-666.

Bradfield, E.G. and C.G. Guttridge. 1979. The dependence of calcium transport and leaf tipburn in strawberry on relative humidity and nutrient solution concentration. Ann. Bot. 43:363-372.

Cerda, A., F.T. Bingham, and C.K. Labanauskas. 1979. Blossom-end rot of tomato fruit as influenced by osmotic potential and phosphorous concentrations of nutrient solution media. J. Amer. Soc. Hort. Sci. 104:236-239.

Chiu, T. and C. Bould. 1976. Effects of shortage of calcium and other cations on ${ }^{45} \mathrm{Ca}$ mobility, growth and nutritional disorders of tomato plants (Lycopersicon esculentum). J. Sci. Food Agr. 27:969-977.

Clarkson, D.T. 1984. Calcium transport between tissues and its distribution in the plant. Plant Cell Environ. 7:449-456.

Collier, G.F. and T.W. Tibbitts. 1982. Tipburn of lettuce. Hort. Rev. 4:49-65.

Cresswell, G.C. 1991. Effect of lowering nutrient solution concentration at night on leaf calcium levels and the incidence of tipburn in lettuce (var. Gloria). J. Plant Nutr. 14: 913-924.

Demarty, M., C. Morvan, M. Thellier. 1984. Calcium and the cell wall. Plant Cell Environ. 7:441-448.

Fallahi, E., T.L. Righetti, and J.T. Raese. 1988. Ranking tissue mineral analyses to identify mineral limitations on quality in fruit. J. Amer. Soc. Hort. Sci. 113(3):382-389.

Hammer, P.A., T.W. Tibbitts, R.W. Langhans, and J.C. McFarlane. 1978. Base-line growth studies of 'Grand Rapids' lettuce in controlled environments. J. Amer. Soc. Hort. Sci. 103:649-655.

Hocking, P.J. 1980. The composition of phloem exudate and xylem sap from tree tobacco (Nicotiana glauca Grah.) Ann. Bot. 45:633-645.

Hopfinger, J.A. and B.W. Poovaiah. 1979. Calcium and magnesium gradients in apples with bitter pit. Comm. Soil Sci. Plant Anal. 10:57-65.

Huett, D.O. 1994. Growth, nutrient uptake and tipburn severity of hydroponic lettuce in response to electrical conductivity and $\mathrm{K}$ : Ca ratio in solution. Austral. J. Agr. Res. 45:251-267.

Jeschke, W.D. and J.S. Pate. 1991. Modelling of the partitioning, assimilation and storage of nitrate within root and shoot organs of castor bean (Ricinus communis L.). J. Expt. Bot. 42:1091-1103.

Kirkby, E.A. and A.H. Knight. 1977. Incluence of the level of nitrate nutrition on ion uptake and assimilation, organic acid accumulation, and cation-anion balance in whole tomato plants. Plant Physiol. 60:349353.

Loneragan, J.F. and K. Snowball. 1969. Calcium requirements of plants. Austral. J. Agr. Res. 20:465-478.

Marschner, H. 1983. General introduction to the mineral nutrition of plants, p. 5-60. In: A. Lauchli and R.L. Bielski (eds.). Encyclopedia of plant physiology. Inorganic plant nutrition. vol. 15A. Springer Verlag, New York.

Marschner, H. 1995. Mineral nutrition of higher plants. Academic Press, New York.

Millikan, C.R. and B.C. Hanger. 1964. Effect of calcium level in the substrate on the distribution of ${ }^{45} \mathrm{Ca}$ in subterranean clover (Trifolium subterraneum L.). Austral. J. Biol. Sci. 17:823-844.

Misaghi, I.J. and R.G. Grogan. 1978. Physiological basis for tipburn develoment in head lettuce. Phytopathology 68:1738-1743.

Olson, K.C., T.W. Tibbitts, and B.E. Struckmeyer. 1969. Leaf histogenesis in Lactuca sativa with emphasis upon laticifer ontogeny. Amer. J. Bot. 56:1212-1216.

Palzkill, D.A., T.W. Tibbitts, and B.E. Struckmeyer. 1980. High relative humidity promotes tipburn on young cabbage plants. HortScience 15:659-660.

Pate, J.S. and P.J. Hocking. 1978. Phloem and xylem transport in the supply of minerals to a developing legume (Lupinus albus L.) fruit. Ann. Bot. 42:911-921.

Pressman, E., R. Shaked, and L. Arcan. 1993. The effect of flowerinducing factors on leaf tipburn formation in Chinese cabbage. J. Plant Physiol. 141(2):210-214.

Thibodeau, P.O. and P.L. Minotti. 1969. The influence of calcium on the development of lettuce tipburn. J. Amer. Soc. Hort. Sci. 94:372-376.

Thiec, D.L., M. Dixon, and J.P. Garrec. 1995. Distribution and variations of potassium and calcium in different cross sections of Picea abies (L.) Karst needles and Fagus sylvatica (L.) leaves exposed to ozone and mild water stress. Ann. Sci. For. 52:411-422.

Tibbitts, T.W. and D.A. Palzkill. 1979. Requirement for root pressure flow to provide adequate calcium to low-transpiring tissue. In: C.B. Shear (ed.). Symp. Ca nutrition of economic crops. Commu. Soil Sci. Plant Anal. 10:251-257.

Tibbitts, T.W., R. Setiamihardja, D.P. Palzkill, and D.M. Olszyk. 1983. Calcium-related leaf necrosis of seedling carrots. J. Amer. Soc. Hort. Sci. 108:1017-1019.

Van Berkel, N. 1988. Preventing tipburn in Chinese cabbage by high relative humidity during the night. Neth. J. Agr. Sci. 36:301-308.

Van Egmond, F. and H. Breteler. 1972. Nitrate reductase activity and oxalate content of sugar-beet leaves. Neth. J. Agr. Sci. 20:193-198. 